\title{
Two unrecorded Elymus taxa (Poaceae) newly added to Korean flora: E. humidus and E. shandongensis
}

\author{
Seung Se CHOI, Jonghwan KIM ${ }^{1 *}$, Yu Cheol PARK and Chul Hwan KIM ${ }^{2 *}$ \\ Team of National Ecosystem Survey, National Institute of Ecology, Seocheon 33657, Korea \\ ${ }^{I}$ Sung-ho Green Tech, Jangseong 57248, Korea \\ ${ }^{2}$ The Korean Association for Survey \& Assessment of Ecosystem, Anyang 14059, Korea \\ (Received 15 June 2021; Revised 9 August 2021; Accepted 14 September 2021)
}

\begin{abstract}
Given that the Korean genus Elymus L. (Poaceae) is often confused with Agropyron Gaertn., the categories and characteristics of Elymus s.l. have been reviewed morphologically. Two unrecorded taxa of Elymus, E. humidus (Ohwi \& Sakam.) T. Osada and E. shandongensis B. Salomon, not previously recorded in Korean flora to date, we report here as an unrecorded species based on samples collected from Chungcheongbuk-do, Gyeongsangnam-do, Jeollanam-do, and Jeollabuk-do. E. humidus is distinguished from other taxa in terms of its habitat around riversides, erect inflorescences, spikelets appressed to rachides of inflorescence, and new individuals asexually propagated at the lower nodes of aerial stems. E. shandongensis is similar to $E$. tsukushiensis var. transiens (Hack.) H. Osada but is distinguished by the flowering time, slightly curved inflorescences, number of veins of the glumes, and spikelets appressed to the rachides. Descriptions of the two unrecorded Korean taxa, photographs, and keys to neighboring taxa are presented.
\end{abstract}

Keywords: unrecorded taxa, Poaceae, Elymus, E. humidis, E. shandongensis, Korea

Poaceae is known to be distributed in 700-771 genera and 11,000-12,000 species worldwide (Chen et al., 2006; Soreng et al., 2015), and is a large taxon consisting of 12 subfamilies and 51 tribes taxonomically (Soreng et al., 2015). Poaceae growing on the Korean peninsula differ in the list and number of taxa by authors because it is difficult to accurately determine the number of taxa, including plants distributed in North Korea, which cannot be investigated, as well as due to the number of newly introduced and added foreign species each year. Park et al. (2011) recorded 96 genera and 252 taxa, including foreign taxa, except for the northern region, while Lee (2018) mentioned 94 genera and 212 taxa, which were missing a number of foreign species. Therefore, Poaceae distributed on the Korean peninsula is expected to comprise over 300 taxa (Cho et al., 2016), including species distributed only in the northern region, and foreign species.

As part of a recent national survey of the natural environment, we collected Elymus humidus (Ohwi \& Sakam.) T. Osada and E. shandongensis B. Salomon, which has not been recorded before in Korea, in several regions, including Jeollanam-do. In this study, the two taxa that are to be presented as unrecorded plants in Korea are included in the tribe Triticeae Dumort within the subfamily Pooideae Benth. (Osada, 1989; Chen and Zhu, 2006). The tribe Triticeae is mainly distributed in the temperate zone of the Northern Hemisphere, and, taxonomically, consists of as few as 330 species in 20 genera to as many as 503 species in 27 genera, except nothogenera (Chen and Zhu, 2006; Cabi, 2010; Soreng et al., 2015). The tribe contains economically important cereals, such as wheat (Triticum aestivium L.), barley (Hordeum vulgare L.), and rye (Secale cereale L.). Elymus sensu lato, consists of 170-180 species worldwide and is the largest taxon within the tribe (Chen and Zhu, 2006; Cabi, 2010). However, most Korean authors have divided the taxa related to the Elymus s.l. into two genera according to the traditional genus concept, which has been treated as an Agropyron Gaertn. with a 1-spikelet at each node of the inflorescence rachides and an Elymus with 2-spikelets at each node of the rachides (Lee, 1989; Lee, 1996; Lee, 2018).

\footnotetext{
*Author for correspondence: plantaxa@hanmail.net (Chul Hwan Kim is deceased), sukoook@empass.com
} 
In this paper, we review the taxonomy of Korean Elymus, including descriptions and key to the genera in tribe Triticeae, and present a revised key to the taxa of Korean Elymus s.l., that includes two newly recorded species in this study.

\section{Delimitation of Korean Elymus s.I.}

Elymus L., Sp. Pl. 83, 1753.-TYPE: E. sibiricus L. (Lectotype designated by Hitchcock, 1929).

Roegneria K. Koch, Linnaea 21: 413, 1848; Campeiostachys Drobow, Fl. Uzbekistan 1: 300, 540, 1941; Semeiostachys Drobow, Fl. Uzbekistan 1: 281, 539, 1941.

Korean name: 갯보리속 (Gaet-bo-ri-sok).

Herbs perennial, caespitose, rarely with rhizomes. Culms obliquely ascending to erect. Leaf blades linear, flat or rolled. Inflorescences with spikes, usually long and loose, linear. Spikes erect to nodding. Spikelets $1(-2)$ or $2(-4)$ at each nodes of rachides, sessile, usually appressed to rachides, with 2-10 or more florets. Glumes 2, subequal, well developed, linearlanceolate to ovate, smaller than lemmas, $(1-) 3-9(-11)$ veined, veins converging to apices, not keeled, apices unawned or shortly awned. Lemmas as long as paleas, 5 veined, usually with long awned apices. Caryopses adherent to lemmas and paleas.

Taxa of the tribe Triticeae in Korea are distinguished from other tribes within the subfamily, in that they have spike inflorescences, most of them have spikelets composed of two or more florets, and each spikelets are sessile or rarely very short stalks (Lee, 2018). Triticeae consist of seven genera, namely Secale L., Triticum L., Hordeum L., Aegilops L., Hystrix Moench, Leymus Hochst., and Elymus s.l. Most of these taxa are directly or indirectly related to the Elymus taxonomically, with the exception of S. cereale L., T. aestivum L., and H. vulgare L., which are planted as annual crops. According to major domestic literature (Lee, 1989; Lee, 1996; Lee, 2018), Korean Elymus s.l. has traditionally been recognized as Elymus if there are two or more spikelets at each node of the inflorescence rachides, and Agropyron if there is one spikelet at the node of the rachides. Meanwhile, among the taxa with two spikelets at each node of the rachides, some taxa with weakly developing nearly veinless glumes have been treated as Hystrix (or Asperella Humb., illegitimate name) (Table 1).

As shown in Table 1, Agropyron has been known to be distributed in approximately 5 species in Korea. However, in many studies on the taxonomy of tribe Triticeae, accepting the view of Nevski (1934), the genus Agropyron s.s. was morphologically limited to include only taxa with one spikelet at each node of the rachides and with distinct 1-keeled glumes. As a result, approximately 10-15 Agropyron species are distributed worldwide
(Dewey, 1986; Chen and Zhu, 2006). In addition to the characteristics of the glumes described above, this taxon usually has short oblong inflorescences and short internodes of the inflorescence rachides. On the other hand, Elymus s.l. can be distinguished from Agropyron s.s. in that each node of the inflorescence rachides has one or two spikelets, there is no distinct keel in glumes, and the linear or broad linear inflorescences have long internodes.

According to the current taxonomic studies, most taxa treated as Agropyron in Korea are included in the Elymus; Elymus ciliaris (Trin.) Tzvelev [= Agropyron ciliare (Trin.) Franch.], E. tsukushiensis var. transiens (back) Osada $[=A$. tsukushiense var. Transiens (back) Ohwi], E. gmelinii (Ledeb.) Tzvelev [= A. gmelinii (Ledeb.) Scribn. \& J. G. Sm., A. turczaninowii Drobow], E. nakaii (Kitag.) S. L. Chen [= A. nakaii Kitag.], and E. repens (L.) Gould [= A. repens (L.) P. Beauv.]. On the other hand, among the taxa treated as Elymus or Agropyron in Korea, some taxa belong to the genera Leymus and Hystrix; Leymus mollis (Trin.) Pilg. [=E. mollis Trin], L. chinensis (Trin. ex Bunge) Tzvelev $[=A$. chinense (Trin. Ex Bunge) Ohwi], and Hystrix coreana (Honda) Ohwi [= E. coreanus Honda].

Therefore, the taxa belonging to the Agropyron s.s. were not distributed in Korea (Table 1). According to the flora of China (Chen and Zhu, 2006), it was mentioned that A. cristatum (L.) Gaertn. was also distributed in Korea, but it has not been confirmed. Considering the geographical distribution, this taxon may be distributed in the northern region, but has not been mentioned in the flora of North Korea (Kim, 2000). As a result, according to the related literature (Chung, 1957; Chung, 1965; Lee, 1989; Lee, 1996; Kim, 2000; Park et al., 2011; Cho et al., 2016; Lee, 2018), there are currently 14 species and seven varieties of three genera directly and indirectly related to the Elymus s.l. within tribe Triticeae in the Korean peninsula; E. ciliaris var. amurensis (Drobow) S. L. Chen, E. ciliaris var. hackelianus (Honda) G. H. Zhu \& S. L. Chen, E. ciliaris var. lasiophyllus (Kitag.) S. L. Chen, E. ciliaris var. submuticus (Honda) S. L. Chen, E. dahuricus Turcz. ex Griseb., E. dahuricus var. cylindricus Franch. (northern), E. excelsus Turcz. ex Griseb. (northern), E. gmelinii, E. mayebaranus (Honda) S. L. Chen (unconfirmed), E. nakaii (northern), E. sibiricus L. (northern), E. tsukushiensis var. transiens, E. yezoensis, E. yezoensis var. koryoensis, and foreign species E. repens (L.) Gould; Hystrix coreana, $H$. longearistata (Hack.) Honda; Leymus chinensis (northern), $L$. mollis, and L. secalinus (Georgi) Tzvelev (northern).

In particular, Hystrix is included in the Elymus by some authors (Soreng et al., 2015), but it is also distinguished in that the glumes are weakly developed or sometimes absent, the 
Table 1. Categories of Korean Elymus s.l. and related taxa by authors and countries.

\begin{tabular}{|c|c|c|c|c|c|c|c|c|c|c|c|c|}
\hline \multirow{2}{*}{$\begin{array}{l}\text { Characteri } \\
\text { stics }^{\mathrm{a}}\end{array}$} & \multirow{2}{*}{$\begin{array}{l}\text { i Specific epithets of Korean } \\
\text { Elymus \& related taxa }\end{array}$} & \multicolumn{6}{|c|}{ Flora of Korea } & \multicolumn{2}{|c|}{ Flora of Japan } & \multirow{2}{*}{$\begin{array}{c}\begin{array}{c}\text { Flora of } \\
\text { China }\end{array} \\
\text { Chen et al. } \\
(2006)\end{array}$} & \multirow{2}{*}{$\begin{array}{c}\begin{array}{c}\text { Flora of N. } \\
\text { America }\end{array} \\
\text { Barkworth et al. } \\
(2007)\end{array}$} & \multirow[t]{2}{*}{ This study } \\
\hline & & $\begin{array}{l}\text { Chung } \\
(1965)\end{array}$ & $\begin{array}{l}\text { Lee } \\
(1989)\end{array}$ & $\begin{array}{c}\text { Lee } \\
(1996)\end{array}$ & $\begin{array}{l}\text { Lee } \\
(2018)\end{array}$ & $\begin{array}{l}\text { Park et al. } \\
\quad(2011)\end{array}$ & $\begin{array}{l}\text { Cho et al. } \\
\text { (2016) }\end{array}$ & $\begin{array}{l}\text { Ohwi } \\
(1984)\end{array}$ & $\begin{array}{l}\text { Osada } \\
(1989)\end{array}$ & & & \\
\hline \multirow[t]{7}{*}{1} & ciliare or ciliaris & Agr & Agr & Agr & Agr & Ely & Agr & Agr & Ely & Ely & Ely & Ely \\
\hline & tsukushiensis var. transiens & Agr & Agr & Agr & Agr & Ely & Agr & Agr & Ely & $\begin{array}{c}\text { Ely } \\
\text { (as kamoji) }\end{array}$ & Ely & Ely \\
\hline & turczaninowii & Agr & Agr & $\begin{array}{c}\text { Agr } \\
\text { (as gmelinii) }\end{array}$ & Agr & - & Agr & $\mathrm{Ag}$ & $\begin{array}{c}\text { Ely } \\
\text { (as gmelinii) }\end{array}$ & $\begin{array}{c}\text { Ely } \\
\text { (as gmelinii) }\end{array}$ & - & $\begin{array}{c}\text { Ely } \\
\text { (as gmelinii) }\end{array}$ \\
\hline & repens & - & - & - & - & Ely & Agr & Agr & Ely & Ely & Ely & Ely \\
\hline & yesoense or yesoensis & Agr & Agr & Agr & Ely & Ely & Agr & Agr & Ely & - & - & Ely \\
\hline & shandongensis ${ }^{\mathrm{b}}$ & & & & & & & - & - & Ely & - & Ely \\
\hline & humidus $^{\mathrm{b}}$ & & & & & & & Agr & Ely & Ely & - & Ely \\
\hline \multirow{6}{*}{$\begin{array}{c}2 \\
\text { or } \\
\text { more }\end{array}$} & chinense or chinensis & Agr & Agr & Agr & Agr & -, Ley? & Ley & - & - & Ley & - & Ley \\
\hline & mollis & Ely & Ely & Ely & Ely & Ely & Ley & Ely & Ley & Ley & Ley & Ley \\
\hline & dahuricus & Ely & Ely & Ely & Ely & Ely & Ely & Ely & Ely & Ely & - & Ely \\
\hline & sibiricus & Ely & Ely & Ely & Ely & Ely & Ely & Ely & Ely & Ely & Ely & Ely \\
\hline & longearistata & Asp & Asp & Asp & Asp & Hys & Hys & Asp & Hys & - & -, Ely? & Hys \\
\hline & coreanus or coreana & Ely & - & Ely & Ely & -, Hys? & Hys & - & - & Hys & -, Ely? & Hys \\
\hline
\end{tabular}

Generic name: Agr, Agropyron; Asp, Asperella nom illeg.; Ely, Elymus; Ley, Leymus; Hys, Hystrix including Asperella

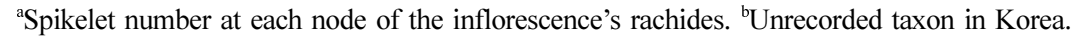


Table 2. Comparison of some characteristics of Korean Elymus taxa with 1 spikelet at each node of the inflorescence.

\begin{tabular}{|c|c|c|c|c|c|c|c|}
\hline \multirow{2}{*}{ Characteristics } & \multicolumn{7}{|c|}{ Elymus (formerly known as Agropyron in Korea) } \\
\hline & ciliaris & tsukuensis var. transiens & yezoensis & gmelinii & humidus & shandongensis & repens \\
\hline Creeping rhizomes & $x$ & $x$ & $\times$ & $\times$ & $x$ & $x$ & o \\
\hline $\begin{array}{l}\text { Asexual propagation } \\
\text { at nodes of lower stems }\end{array}$ & $x$ & $x$ & $x$ & $x$ & o & $\times$ & $x$ \\
\hline Spikes at anthesis & Nodding & Curved & Nodding & Slightly curved & Erect & Slightly curved & Erect \\
\hline Spikelets length $(\mathrm{cm})$ & $1.0-2.0$ & $1.5-2.5$ & $1.5-2.0$ & $1.5-2.0$ & $1.7-2.2$ & $1.2-2.0$ & $0.8-1.7$ \\
\hline Florets (no.) & $5-12$ & $5-10$ & $3-7$ & $5-7$ & $4-7$ & $5-8$ & $5-7$ \\
\hline Glume length $(\mathrm{cm})$ & $0.5-1.0$ & $0.5-0.8$ & $0.6-0.8$ & $0.6-1.2$ & $0.6-0.8$ & $0.6-0.9$ & $0.5-1.5$ \\
\hline Veins (no.) & $5-7$ & $3-5$ & $3-5$ & $5-7$ & $3-5$ & $5-7$ & $5-7$ \\
\hline Calluses & Smooth & Smooth & Hairy & Hairy & Smooth & Smooth & Smooth \\
\hline Lemma length $(\mathrm{cm})$ & $0.7-1.2$ & $0.8-1.2$ & $0.7-1.0$ & $0.7-1.2$ & $0.8-1.2$ & $0.9-1.0$ & $0.6-1.2$ \\
\hline Veins (no.) & 5 & 5 & 5 & 5 & 5 & 5 & 5 \\
\hline Awns (cm) & $1.5-3$ & $1.5-3$ & $1.5-2.5$ & $2.5-3.5$ & $2-3$ & $2-3$ & 0 -ca. 0.2 \\
\hline $\begin{array}{l}\text { Lemma's awns at } \\
\text { fruiting period }\end{array}$ & Recurved & Erect & Erect & Recurved & Erect & Erect & Erect \\
\hline $\begin{array}{l}\text { Length ratio of lemmas } \\
\text { and paleas }\end{array}$ & Lemma $>$ palea & Subequal & Subequal & Subequal & Subequal & $\begin{array}{l}\text { Slightly lemma> } \\
\text { palea }\end{array}$ & Subequal \\
\hline Habitats & $\begin{array}{l}\text { Roadside or } \\
\text { meadow }\end{array}$ & $\begin{array}{l}\text { Roadside or } \\
\text { meadow }\end{array}$ & Mountain & Mountain & Riverside & $\begin{array}{l}\text { Roadside or } \\
\text { meadow }\end{array}$ & $\begin{array}{l}\text { Roadside } \\
\text { or meadow }\end{array}$ \\
\hline Flowering & May to Jun & May to Jun & Jun to Jul & Jun to Jul & May to Jun & Jul to Aug & May to Jun \\
\hline
\end{tabular}

glumes have nearly no veins, and the leaf blades are herbaceous and flexible (Osada, 1989; Chen and Zhu, 2006; Lee, 2018). Taxa belonging to the Leymus are usually included in the Elymus in Korea, but many authors (Osada, 1989; Chen and Zhu, 2006; Cabi, 2010; Soreng at al., 2015) have treated it as a separate genus from other genera.

The key to the genera of tribe Triticeae within subfamily Pooideae growing in Korea, including Elymus s.l, is described below.

\section{Key to the Korean tribe Triticeae including genus Elymus s.I. within subfamily Pooideae}

1. Spike inflorescences with 2 or more spikelets at each node of the rachides.

2. Spikelets with $1(-2)$ florets, three at each node of the rachides, usually central spikelets sessile and fertile, lateral ones pedicellate and sterile, sometimes all sessile in cultivated plants ……… Hordeum 보리속

2. Spikelets with (1-)2-10 florets, 2-3 [sometimes 4-6] at each node of rachides, usually all sessile.

3. Internodes of rachides easily visible; spikelets with (1-)2-4 florets; glumes nearly vestigial or weakly developed, subulate to linear * Hystrix 수염개밀속 3 . Internodes of rachides hardly visible; spikelets with 2-10 florets; glumes well developed, linearlanceolate to ovate.

4. Plants usually tufts, rarely with rhizomes; distal glumes usually at least 3-7(-9) veined, generally not keeled; lemmas usually with long awned apices ……........................ Elymus 갯보리속

4. Plants usually rhizomatous; glumes 1-3(-5) veined, often keeled; lemmas with unawned or shortly awned apices ……… Leymus 갯그령속

1. Spike inflorescences with generally 1 spikelet at each node of the rachides.

5. Glumes 1 or 3-9 veined, veins converging toward apices, acute to shortly awned apices.

6. Plants perennial; spikes somewhat lax; glumes usually lanceolate to narrowly ovate and 3-9 veined; spikelets with usually $5-10$ or more florets

Elymus

(formerly known as Agropyron in Korea) 갯보리속

6. Plants annual; spikes dense; glumes linear or subulate and 1 veined; spikelets with 2 florets ..... Secale 호밀속 
5. Glumes 3-10 veined, veins parallel or divergent, truncate, or toothed with at least 1 long awned apices.

7. Spikes somewhat dense; internodes of rachides short, not easily visible; glumes keeled and 3-10 veined ..

Triticum 밀속

7. Spikes lax; internodes of rachides are $0.6-1.2 \mathrm{~cm}$ long, somewhat long, easily visible; glumes not keeled and 7-10 veined ………………….... Aegilops 염소풀속

\section{Taxonomic Treatments}

1. Elymus humidus (Ohwi \& Sakam.) T. Osada, Illustr. Grasses of Japan 426, 738, 1989; Agropyron humidum Ohwi \& Sakam., J. Jap. Bot. 39: 109, 1964; Elymus humidorus (Ohwi \& Sakam.) Á. Löve, Feddes Repert. 95: 457, 1984; Campeiostachys humidora (Ohwi \& Sakam.) B. R. Baum, J. L. Yang \& C. Yen, J. Syst. Evol. 49: 153, 2011.-TYPE: Japan. Honshu: Koshigaya, in paddy field, 8 May 1950, J. Ohwi TNS (NSM) No. 5 (TNS, not seen) (Fig. 1).

Korean name: 둔치개밀 (Dun-chi-gae-mil).

Herbs perennial. Culms tufted, erect and geniculate at bases, 40-80 cm tall; new branches and roots emerge from lower nodes of ground fallen stems after anthesis and proliferate new individuals next year asexually. Leaf sheaths glabrous. Leaf blades 7-20 × 0.3-0.7 cm, flat, scaberulous on upper surfaces and at margins, glabrous on lower surfaces; ligules ca. $0.7 \mathrm{~mm}$ tall, glabrous, hyaline membranous, erose margins. Inflorescences with erect and straight spikes; spikes 10-20 cm long, somewhat sparsely spikelets, sessile; internodes of rachides scaberulous, ca. $1-1.3 \mathrm{~cm}$ long (the lowest up to $2.5-$ $3.3 \mathrm{~cm})$. Spikelets 1 at each nodes of rachides, tightly appressed to rachides even in anthesis, 1.7-2.2(-2.5) cm long, with 4-7 florets, pale green or purple-tinged or brown. Glumes 2, widely lanceolate, subequal, 6-8 mm long, 3-5(-7) veined, apices acuminate or sometimes shortly awned, scaberulous along upper mid-veins. Lemmas lanceolate, $0.8-1.2 \mathrm{~cm}$ long, scaberulous along upper veins or nearly so, 5 veined, with stout and straight awned apices, awns up to $3 \mathrm{~cm}$ long; calluses glabrous. Paleas nearly equal to lemmas, scaberulous at margins. Anthers yellow, ca. $2.5 \mathrm{~mm}$ long.

Flowering: May to June.

Habitat: Hundreds of individuals grow along the humid grassland around the slightly raised edges of the riverside (Fig. 1E). The habitat is an area where water can easily overflow during the summer flood, and seeds are expected to be relatively easily dispersed by the flow of the water. However, this taxon is known to grow in humid places around paddy fields where there is a lot of artificial interference in Japan.

Considering the characteristics of its habitat, population, and individuals, we believe it is worth being considered a domestic legally protected species. In Japan, it is treated as a vulnerable species (Environment Agency of Japan, 2000; Ibaragi et al., 2009).

Distribution: Japan (Honshu, Kyushu, Shikoku) [from Ohwi and Sakamoto, 1964; Ibaragi et al., 2009], Korea (Hwasungun, Jeollanam-do); Japanese populations are naturalized, according to Ohwi and Sakamoto.

Specimens examined: KOREA. Jeollanam-do: Hwasungun, Nam-myeon, riverside in Jusan-ri, 4 Jun 2017, J.H. Kim 174208 (2 sheets, JNU); Hwasun-gun, Nam-myeon, riverside in Sasu-ri, 12 Jun 2020, C.H. Kim et al. 20200034 (5 sheets, JNU).

This species was treated as a part of Elymus mayebaranus [= Agropyron mayebaranum Honda] but was published as a new species based on type specimen collected from Honshu, Japan (Ohwi [TNS (NSM) 5]) by Ohwi and Sakamoto (1964). Elymus mayebaranus is a sterile species originating from the hybridization of E. tsukushiensis var. transiens and E. humidus, and has been known to be distributed in China, Taiwan, and Japan in the past (Ohwi, 1984; Osada, 1989). However, its distribution in China and Taiwan may be inaccurate due to misidentification with E. shandongensis B. Salomon or $E$. tsukushiensis var. transiens, and is now treated as endemic to Japan (Chen and Zhu, 2006; Jung and Chen, 2013).

According to IPNI (ipni.org), Ohwi (1965: 154) corrected the specific epithet humidum to humidorum, citing Agropyron humidorum Ohwi \& Sakam., but the correction was rejected. Therefore all combinations with specific epithets "humidorum, humidorus, and humidora" are invalid.

Elymus humidus (Ohwi \& Sakam.) T. Osada is significantly different from other taxa, including $E$. dahuricus with 2 spikelets at each node of inflorescence rachides, by having 1 spikelet at each node of the rachides. In addition, this species is easily distinguished from E. ciliaris, which is remarkably different in length, because of the similar lengths of lemmas and paleas. This taxon differs from E. tsukushiensis var. transiens and most other taxa, which have curved or nodding inflorescences in the flowering period, by having always erect inflorescences and relatively thicker rachides. In addition, this species always has spikelets appressed to the rachides of the inflorescence, while E. tsukushiensis var. transiens have spikelets that spread slightly or ascend from curved rachides during the flowering period. It is also distinguished from $E$. gmelinii and E. ciliaris, which have strongly recurved lemma awns in the fruiting period, and E. yezoensis, which has stiff 


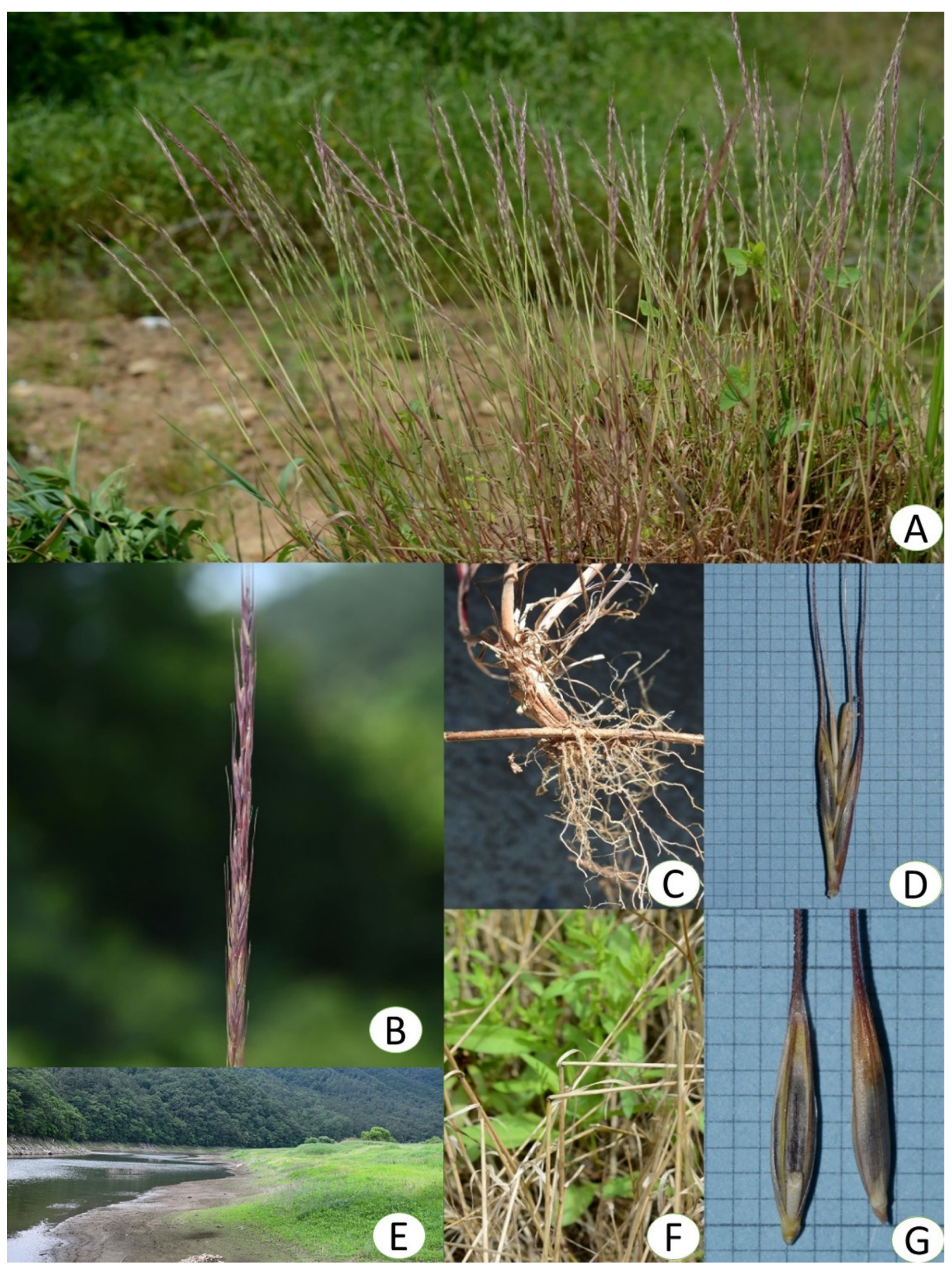

Fig. 1. Elymus humidus as a new record in the Korean flora. A. Habitat. B. Spike inflorescence with several spikelets. C. Node with new roots. D. Spikelet. E. Growing on a slightly raised edge of the riverside. F. Broken culms at uppermost nodes. G. Lemma with paleas. 
hairy calluses, by having erect lemma's awns and smooth calluses (Table 1).

Meanwhile, as Ohwi and Sakamoto (1964) reported, since E. humidus grows only around the waterside, it is distinguished from taxa growing around roadsides or grassy fields in lowlands, such as E. tsukushiensis var. transiens, and taxa in mountainous areas, such as E. yezoensis.

In particular, E. humidus propagates asexually in addition to normal seed dispersal (Ohwi and Sakamoto, 1964; Osada, 1989; Ibaragi et al., 2009). This species is cut off the uppermost nodes of stems including inflorescence by wind or physical forces after maturation (Fig. 1F). It has been confirmed that new shoots and roots emerged from the nodes of the lower aerial stems that fell to the ground and propagated as new individuals the following year (Fig. 1C). Among the tribe Triticeae, E. humidus is the only species that produces individuals using this asexual method.

According to Ohwi and Sakamoto (1964), it was analyzed that $E$. humidus had previously been introduced into Japan from China with seeds of Astragalus sinicus L. [Fabaceae] or forage crops; however, this species is not mentioned in the flora of China (Chen and Zhu, 2006). Therefore, this species is currently distributed only in Korea and Japan. As Ohwi and Sakamoto pointed out, if it is true that Japanese populations originated from other countries, and it is not distributed in geographically adjacent China or Taiwan, the possibility of it being endemic to Korea must be carefully considered.

The Korean name of this species was given "Dun-chi-gaemil" due to its habitat being found on a slightly raised edge of the riverside, known as Dun-chi in Korean.

2. Elymus shandongensis B. Salomon, Willdenowia 19: 449, 1990; Roegneria shandongensis (B. Salomon) J. L. Yang, Y. H. Zhou \& C. Yen, Guihaia 17: 22, 1997.—TYPE: China. Shandong province, Qingdao, F. C. Keng 6507 (N, not seen) (Fig. 2).

Korean name: 여름개밀 (Yeo-reum-gae-mil).

Herbs perennial. Culms laxly tufted, erect or slightly geniculate at bases, 0.6-1 m tall. Leaf sheaths somewhat long hairy at margins; ligules ca. $0.6 \mathrm{~mm}$ long. Leaf blades 10-25 $\times 0.4-0.8 \mathrm{~cm}$, flat or involute and scaberulous at margins, both surfaces scaberulous or nearly so. Inflorescences with early erect and slightly curved spikes at anthesis, spikes 5-20 cm long. somewhat sparsely spikelets, sessile; internodes of rachides scaberulous, ca. $1-2 \mathrm{~cm}$ long. Spikelets 1 at each nodes of rachides, appressed to rachides, $1.2-2.0 \mathrm{~cm}$, with $5-$ 8 florets. Glumes 2, oblong-lanceolate, subequal, proximal glumes 6-9 mm long, distal ones 7-9 mm long, 5-7(-9) veined, apices acute or shortly awned. Lemmas oblonglanceolate, 9-10 $\mathrm{mm}$ long, margins membranous, awn erect, $15-30 \mathrm{~mm}$; calluses smooth or nearly so. Paleas slightly small to lemmas, margins scabrous.

Flowering: July to August.

Habitat: A large number of individuals grow on sunny roadsides around agricultural lands where there is a lot of artificial interference (Fig. 2E), sometimes growing together with E. ciliaris and/or E. tsukushiensis var. transiens.

Distribution: China (central and southeastern region) (Chen and Zhu, 2006; Jung and Chen, 2013), Korea.

Specimens examined: KOREA. Chungcheongbuk-do: Jecheon-si, Susan-myeon, Wondae-ri, alt. 261 m, 25 Aug 2017, Kim J. H. 174432 (1 sheet, JNU). Jeollabuk-do: Jinan-gun, Jucheon-myeon, Unbong-ri, alt. 313 m, 14 Jul 2017, Kim J. H. 174296 (1 sheet, JNU); Kunsan-si, Napo-myeon, roadside in Jugok-ri, elev. 30 m, 17 Jul 2020, Kim, C. H. \& S. S. Choi 20200035 (7 sheets, JNU). Gyeongsangnam-do: Uiryeong-gun, Daeui-myeon, Haengjeong-ri, elev. 203 m, 23 Jul 2017, Kim J. H. 174321 (1 sheet, JNU).

This species was published as E. shandongensis based on the type specimen (F.C. Keng 6507, N) collected from Qingdao, Shandong province in northeastern China (Salomon, 1990), and is recognized as an endemic species that is mainly distributed in the central and southeastern regions of mainland China, including Shandong (Chen and Zhu, 2006; Jung and Chen, 2013). This species was recognized as E. mayebaranus (a hybrid species of E. tsukushiensis var. transiens and $E$. humidus) in China until it was published as a new species (Chen and Zhu, 2006), and is known to be distributed in North Korea (Kim, 2000). As in China, E. mayebaranus, which is known to be distributed in the northern region of Korea, is considered to be very likely to be E. shandongensis.

This species is easily distinguished from taxa with 2 spikelets at each node of inflorescence rachides by having 1 spikelet at each node of rachides, similar to E. humidus, as mentioned above. Not only is this species the most similar in morphology to E. tsukushiensis var. transiens [it is treated as the same taxa as E. kamoji (Ohwi) S. L. Chen in China], but also in the characteristics of its habitats. However, E. shandongensis has spike inflorescences that curve slightly laterally in the flowering period, spikelets that always appressed to the rachides, and glumes that are usually 5-7(-9) veined, whereas E. tsukushiensis var. transiens has spikes that nod strongly toward the ground during flowering, spikelets diverging or ascending from the rachides, and glumes that are 3-5 veined. In addition, this species is also distinguished from other taxa such as $E$. humidus, which always has erect inflorescences, $E$. 


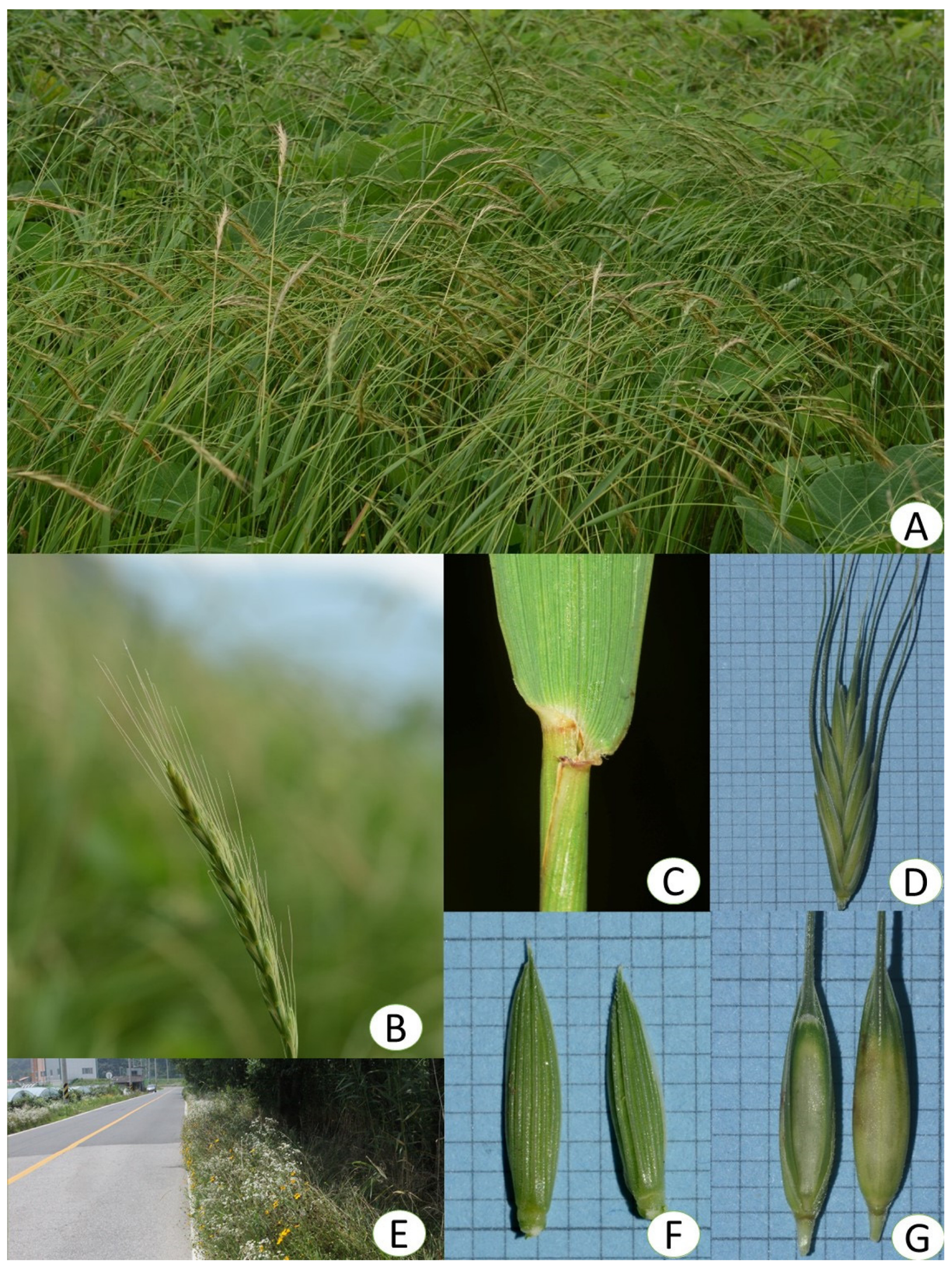

Fig. 2. Elymus shandongensis as a new record in the Korean flora. A. Habitat. B. Inflorescence with several spikelets. C. Ligule. D. Spikelet. E. Growing on the roadside around the farmland. F. Glume. G. Lemmas with paleas. 
ciliaris and E. gmelinii, which have strongly recurved lemma awns during the fruiting period, and E. yezoensis, which has stiff hairy calluses (Table 1).

The Korean name of this species was given "Yeo-reum-gaemil" due to the fact that the flowering period is July, unlike other taxa that bloom in May, including E. ciliaris. Based on the data of our research team, the Korean and scientific names were known to the public through a press release of the National Institute of Biological Resources (NIBR) on June 21, 2019.

As a result, 11 species and 7 varieties of Elymus s.l., including two unrecorded species, are known to be growing on the Korean peninsula. The following key to the species was prepared for them, however, three species and six varieties have been excluded; E. excelsus and E. nakaii, which are known to be distributed in the northern region of the Korean peninsula, E. mayebaranus of uncertain distribution in Korea, and the remaining varieties, except for E. tsukushiensis var. transiens, where the type variety is not distributed in Korea.

\section{Key to the taxa of Korean Elymus s.I.}

1. Spike inflorescences with 2-3 spikelets at each node of the rachides.

2. Spikes erect, somewhat dense; glumes equaling or slightly shorter than lemmas .. E. dahuricus 갯보리

2. Spikes nodding to pendulous, loose; glumes much shorter, nearly $1 / 2$ length of lemmas

E. sibiricus 개보리

1. Spike inflorescences with 1 spikelet at each node of the rachides.

3. Plants with long creeping rhizomes not forming tufts; lemmas awnless to short awned apices, awns up to ca. $0.2 \mathrm{~cm}$ long (up to ca. $1 \mathrm{~cm}$ in some varieties) .

E. repens 구주개밀

3. Plants forming tufts without long creeping rhizomes; lemmas long awned apices, 1-4 cm long (rarely a variety of E. ciliaris, 1-7 mm).

4. Lemmas with recurved awns at fruiting period.

5. Paleas distinctly shorter than lemmas (1/2-2/3), slightly oblanceolate with rounded or emarginate apices; calluses nearly smooth or glabrous; habitats mainly grassy fields or roadsides in cultivated areas or low mountains

E. ciliaris 속털개밀

5. Paleas nearly equaling or slightly shorter than lemmas $(3 / 5-4 / 5)$, oblong with rounded apices; calluses stiff hairy; habitats woods in high mountains E. gmelinii 털개밀
4. Lemmas with always erect awns.

6. Spikes always erect; new branches and roots emerge from lower nodes of ground fallen stems and propagate new individuals asexually; habitats wet riverside edges E. humidus 둔치개밀

6. Spikes strongly nodding or slightly curved at anthesis; not propagate asexually at nodes of ground stems; habitats mostly dry roadsides or grassy fields in cultivated areas, low mountains, or woods in high mountains.

7. Calluses distinctly stiff hairy; habitats woods in high mountains …………… E. yezoensis 자주개밀

7. Calluses smooth or nearly so; habitats roadsides or grassy fields in cultivated areas or low mountains.

8. Spikes strongly nodding at anthesis; spikelets ascending at anthesis, appressed to rachides before and after anthesis; glumes (2-)3-5(-7) veined, much smaller than lemmas; flowering in May and maturing in July

E. tsukushiensis var. transiens 개밀

8. Spikes slightly curved at anthesis; spikelets always appressed to rachides; glumes are 5-7(9) veined, slightly smaller than lemmas; flowering in July and maturing in August or September …….. E. shandongensis 여름개밀

ORCID: Seung Se CHOI https://orcid.org/0000-0002-3332-5544; Jong Hwan KIM https://orcid.org/0000-0003-0271-5969; Yu Chul PARK https://orcid.org/0000-0003-2747-6044; Chul Hwan KIM https://orcid.org/0000-0003-4894-0651

\section{Acknowledgments}

This work was supported by a grant from the 5th National Ecosystem Survey of the National Institute of Ecology (NIE), funded by the Ministry of Environment (MOE) of the Republic of Korea (NIE-A-2021-01).

\section{Conflict of Interest}

The authors declare that there are no conflicts of interest.

\section{Literature Cited}

Barkworth, M. E., J. J. N. Campbell and B. Salomon. 2007. Elymus. In Flora of North America, Vol. 24. Magnoliophyta: Commelinidae (in Part): Poaceae, Part 1. Barkworth, M. E., K. M. C. Capels, S. Long, L. K. Anderton and M. B. Piep (eds.), 
Oxford University Press, New York. Pp. 288-343.

Cabi, E. 2010. Taxonomic revision of the tribe Triticeae Dumortier (Poaceae) in Turkey. PhD dissertation, Middle East Technical University, Ankara, Turkey, 364 pp.

Chen, S.-L. and G.-H. Zhu. 2006. Triticeae. In Flora of China, Vol. 22. Poaceae. Wu, Z.-Y., P. H. Raven and D.-Y. Hong (eds.), Science Press, Beijing and Missouri Botanical Garden Press, St. Louis, MO. Pp. 386-444.

Chen, S., D. Li, G. Zhu, Z. Wu, S. Lu, L. Liu, Z. Wang, C. Wang, B. Sun, Z. Zhu, N. Xia, L. Jia, Z. Guo, W. Chen, X. Chen, G. Yang, S. M. Philips, C. Stapleton, R. J. Soreng, S. G. Aiken, N. N. Tzvelev, P. M. Peterson, S. A. Renvoize, M. V. Olonova and K. H. Ammann. 2006. Introduction of Poaceae (Gramineae). In Flora of China, Vol. 22. Poaceae. Wu, Z.-Y., P. H. Raven and D.Y. Hong (eds.), Science Press, Beijing and Missouri Botanical Garden Press, St. Louis, MO. Pp. 1-7.

Cho, Y. H., J. H. Kim and S. H. Park. 2016. Grasses and Sedges in South Korea. Geobook Press, Seoul. Pp. 39-287. (in Korean)

Chung, I. C. 1965. Korean Grasses. Chicago Natural History Museum, Korea at the Taesutang Press, Seoul. Pp. 77-85.

Chung, T. H. 1957. Korean Flora, Vol. 2. Herbaceous Plants. Sinjisa, Seoul. Pp. 857-934. (in Korean)

Dewey, D. R. 1986. Taxonomy of the crested wheatgrasses (Agropyron). In Crested Wheatgrass: Its Values, Problems and Myths; Symposium Proceedings. Johnson, K. L. (ed.), Utah State University, Logan, UT. Pp. 31-44.

Environment Agency of Japan. 2000. Threatened Species of Japan Red Data Book. 2nd ed. Vol. 8. Vascular Plants. Japan Wildlife Research Center, Tokyo. 664 pp.

Ibaragi, Y., T. Nakamura, S. Kinoshita and M. Ogawa. 2009. Elymus humidus (Ohwi \& Sakam.) Osada (Poaceae) found in Tokushima prefecture, Western Japan. Journal of Japanese Botany 84: 310-312. (in Japanese)

Jung, M.-J. and C.-W. Chen. 2013. Elymus L. (Poaceae) in Taiwan and related species in neighbor areas. Taiwania 58: 53-60.

Kim, H. S. 2000. Agropyron, Aneurolepidium, Asperella, Elymus, Clinelymus. In Flora Coreana, Vol. 8. Im, I. R. (ed.), The Science and Technology Publishing House, Pyongyang. Pp. 218235. (in Korean)

Lee, T. B. 1989. Illustrated Flora of Korea. 4th ed. Hyangmoonsa, Seoul. Pp. 78-127. (in Korean)

Lee, W. T. 1996. Lineamenta Florae Koreae (I). Academy Pub. Co., Seoul. Pp. 1321-1428. (in Korean)

Lee, Y. N. 2018. Poaceae Barnhart. In The Genera of Vascular Plants of Korea. Park. C. W. (ed.), Hongreung Science Press, Seoul. Pp. 1572-1683. (in Korean)

Nevski, S. A. 1934. Tribe XIV. Hordeae Benth. In Flora URSS II. Komarov, V. L. (ed.), Editio Academiae Scientiarum, Leningrad. Pp. 590-728. (in Russian)

Ohwi, J. 1984. Gramineae. In Flora of Japan. Ohwi, J., F. G. Meyer and E. H. Walker (eds.), Smithsonian Institution, Washington, DC. Pp. 131-195.

Ohwi, J. and S. Sakamoto. 1964. Taxonomy, ecology and distribution of Agropyron humidum Ohwi et Sakamoto. Journal of Japanese Botany 39: 109-114.

Osada, T. 1989. Illustrated Grasses of Japan. Heibonsha Ltd., Tokyo. Pp. 400-439.

Park, S. H., Y. M. Lee, S.-Y. Jung, K. S. Chang, U. C. Kang, S. S. Chung, S. H. Oh and J.-C. Yang. 2011. Illustrated Grasses of Korea (Revised and Enlarged Edition), Ridrik Press, Seoul. 600 pp. (in Korean)

Salomon, B. 1990. A new species of Elymus (Poaceae) from China. Willdenowia 19: 449-451.

Soreng, R. J., P. M. Peterson, K. Romaschenko, G. Davidse, F. O. Zuloaga, E. J. Judziewicz, T. S. Filgueiras, J. I. Davis and O. Morrone. 2015. A worldwide phylogenetic classification of the Poaceae (Gramineae). Journal of Systematics and Evolution 53: 117-137. 


\title{
한국 식물상에 새로이 추가되는 벼과 갯보리속의 2 개 미기록 분류군: 둔치개밀, 여름개밀
}

\author{
최승세 · 김종환 ${ }^{1} \cdot$ 박유철 · 김철환 $^{2 *}$
}

국립생태원 자연환경조사팀, ${ }^{1}$ 성호그린테크, ${ }^{2}$ (사)생태계조사평가협회

적 요: 한국산 갯보리속은 개밀속과 혼돈하여 사용하여 온 바, 형태적으로 갯보리속의 범주 및 특성을 재검 토하였고, 이때까지 한반도 식물상에 기록된 바 없는 갯보리속의 2 개 미기록 분류군, 둔치개밀과 여름개밀을 각각 전라남도와 전라북도에서 채집된 표본을 근거로 보고하였다. 둔치개밀은 강가 주변의 생육지, 항상 곧 추서는 꽃차례, 화서에 밀착된 소수, 지상부 아래쪽 마디에서 새로운 개체를 무성적으로 증식하는 점에서 다 른 분류군과 구별되고, 여름개밀은 개밀과 비슷하지만 개화시기가 여름철이고, 옆으로 약간 휘는 꽃차례, 포 령의 맥수, 화서에 밀착된 소수와 같은 특징에 의해 구별되었다. 한국산 두 미기록 분류군에 대한 기재, 사진 및 근연 분류군간의 검색표를 제시하였다.

주요어: 미기록종, 벼과, 갯보리속, 둔치개밀, 여름개밀, 한국산 